\title{
Isolation and Screening of Fungal Isolates for Multienzyme Production Through Submerged and Solid State Fermentations
}

Vijay Kumar Garlapati*, Nikita Maheswari and Ankit Gupta

Bioprocess Engineering Laboratory, Department of Biotechnology and Bioinformatics, Jaypee University of Information Technology, Waknaghat, Himachal Pradesh 173 234, India

\begin{abstract}
Phytases, pectinases, and invertases are three major industrially important enzymes that find significant applications in food, feed, pharmaceutical and environmental sectors. The six isolated fungal species (JUIT, 1-6), isolated from soil Waknaghat, HP, have been identified as Aspergillus sp. through microscopical studies and fruiting body formation. Identified fungal isolates have been screened for multienzymes (Invertase, Pectinase and Phytase) production through solid state and Submerged Fermentations. Among all the fungal strains screened, Aspergillus nidulans (JUIT 4) and Aspergillus niger (JUIT 5) showed the highest coproduction of multi enzymes through Solid State Fermentation using wheat bran and maltose as a substrate and inducer, respectively. The Solid State Fermentation conditions seems to be equal to $2 \mathrm{ml}$ spore suspension, $90 \%$ relative humidity, $0.4 \%$ water activity and $48 \mathrm{~h}$ incubation time. Partial purified (through 70\% ammonium sulphate precipitation) enzymes have been further characterized for effect of $\mathrm{pH}$. The resultant multienzymes complex with phytase, pectinase, and invertase activities may have considerable industrial potential in food and feed industries for fruit juice clarification, phytate elimination and in condiment preparations.
\end{abstract}

Keywords: Isolation; Screening; Aspergillus sp; Phytase; Pectinase; Invertase; Solid state fermentation; Submerged fermentation

\section{Introduction}

Functional integration and the cooperative effect of multienzymes over individual counterparts and have demonstrated its important role in the production of different commodities in food and feed industries. Phytase (myo-inositol hexaphosphate phosphohydrolase, EC 3.1.3.8) is an acid phosphatase enzyme that catalyzes the hydrolysis of phytic acid to less phosphorylated myo-inositol derivatives, have applications in feed \& food industries (for phytate elimination) [1,2]. Pectinase (EC 3.1.1.11) represents for pectic enzymes in brewing (pectolyase, pectozyme and polygalacturonase) have been used in fruit juice extraction and clarification [3]. $\beta$-fructofuranosidase namely invertase (EC 3.2.1.26) is an predominant enzyme used in food (confectionery) industry for catalyzing the hydrolysis of terminal nonreducing $\beta$-fructofuranoside residues of $\beta$-fructofuranosides where fructose is preferred over sucrose due to its sweetness [4].

Multiple enzyme activities in supernatant produced through fermentation facilitates the production of enzyme activities with high titer values with synergetic effects. A selection of précised fermentation conditions is utmost important for achieving these multiple enzyme activities from a microbial supernatant. However, currently there is still no appropriate bioprocess with a well-established bioengineering approach for simultaneous production of multienzymes through a complex microbial culture system. The $\mathrm{pH}$ range of commercially produced fungal enzymes were usually falls in the $\mathrm{pH}$ range of natural substrates to be processed and the enzymes are secreted into the culture media, which makes downstream processing easier for the enzymes. The endowed efficiency of $A$. niger for extracellular phytase production has been acknowledged by several researchers [5-7]. Pectinases are produced by a large number of organisms, such as bacteria, fungi, actinomycetes and yeast. A. niger [8] and B. subtilis [9] are the major sources of several commercial pectinase preparations of Novo Nordisk (PectinexTM, Pectinex SP-L) and Carolina Biological Supply Company, CCM International Ltd. [10,11]. Among microorganisms, the enzymatic activity of invertase has been characterized mainly predominant with the species of Saccharomyces cerevisae, Candida utilis, Aspergillus niger, Thermomyces lanuginosus and Penicillium chrysogenum has been widely studied. A combination of different enzymes often had no negative interaction and would effectively hydrolyze complex substrates of feedstuff [12-14].

Usually, multienzymes are produced through the mixing of individual enzymes through engineered microbes with multifunctions or through mixed culture of microbes $[15,16]$. Due to having disadvantages of their own, the researchers are in search of well single microbe engineered bioprocess which can produce simultaneous multienzymes efficiently. The low substrate cost coupled with higher volumetric productivities of Solid State Fermentation (SSF) seems to be ideal compared to enzyme production through Submerged Fermentation (SmF). Moreover, the conditions of SSF were similar to the fungal habitat conditions. Agro-waste substrate utilization in $\mathrm{SmF}$ is an economical process for production of industrial enzymes such as Invertase, Pectinase and Phytase [17]. Production of multienzymes (pectinase, pectate lyase, cellulose, xylanase, $\beta$-xylosidase and invertase) through SSF have been reported in several instances through utilization Aspergillus, Fusarium, Neurospora and Penicillium sp using orange peel as a substrate [18]. In another study by Delabona et al. [19] multienzyme preparations containing pectinase, cellulase and xylanase enzymes have been produced using six fungal isolates. Among the six fungal isolates tested, Aspergillus niger proved to be the most potent and produced highly active multienzyme systems. Hence, in our present study we have made an attempt to isolate and identify different fungal

*Corresponding author: Vijay Kumar Garlapati, Bioprocess Engineering Laboratory, Department of Biotechnology and Bioinformatics, Jaypee University of Information Technology, Waknaghat, Himachal Pradesh 173 234, India, Tel: +911792-239-225; Fax: +91-017-922-453-62 ; E-mail: shanepati@gmail.com

Received July 29, 2015; Accepted August 14, 2015; Published August 19, 2015

Citation: Garlapati VK, Maheswari N, Gupta A (2015) Isolation and Screening of Fungal Isolates for Multienzyme Production Through Submerged and Solid State Fermentations. J Bioprocess Biotech 5: 249 doi:10.4172/2155-9821.1000249

Copyright: (C) 2015 Garlapati VK, et al. This is an open-access article distributed under the terms of the Creative Commons Attribution License, which permits unrestricted use, distribution, and reproduction in any medium, provided the original author and source are credited. 
isolates with their ability to produce multienzymes (phytase, pectinase and invertase) through SSF and SmF technologies using wheat bran as substrate.

\section{Materials and Methods}

Wheat bran, used as a substrate in SSF, was purchased from local market. Phytic acid was procured from Sigma Life Sciences (USA). Media constituents were purchased from Himedia Laboratories (Mumbai, India) and all other chemicals used were analytical grade and obtained from SRL (Mumbai).

\section{Isolation and maintenance of micro organisms from agricultural field soil}

Soil samples were collected from agricultural fields of Waknaghat, Chandigarh and Delhi, India. Six fungal isolates were obtained from these soil samples using serial dilution method on PDA agar plates. Pure cultures were maintained on PDA slants and were screened for Invertase, Pectinase and Phytase production. Fungal isolates were grown in Potato Dextrose Broth (PDB) at $30^{\circ} \mathrm{C}$ and $120 \mathrm{rpm}$ for $96 \mathrm{~h}$ under submerged conditions.

\section{Screening of fungal isolates for pectinase, invertase and phytase production}

Screening for Phytase production was done by measuring the rate of liberation of inorganic phosphate using phytic acid as substrate [20]. A volume of $0.5 \mathrm{ml}$ of appropriately diluted cell free broth was mixed with $0.5 \mathrm{ml}$ of $0.1 \%$ phytate dodecasodium salt as a substrate, and the mixture was incubated at $50^{\circ} \mathrm{C}$ for $10 \mathrm{~min}$. The reaction was stopped by adding $1 \mathrm{ml}$ of tricholoroacetic acid solution (TCA, 10\% w/v). Color development was achieved by adding $1 \mathrm{ml}$ of reagent (acidified solution of ferrous sulphate and ammonium molybdate). After $10 \mathrm{~min}$ incubation at room temperature, absorbance was measured at $660 \mathrm{~nm}$. The assay was performed in triplicates with an appropriate blank. The controls were prepared by separately incubating substrate and broth with TCA at experimental conditions [20]. One enzyme unit (U) was defined as the amount of enzyme liberating $1 \mu \mathrm{mol}$ of inorganic phosphate per min under standard assay conditions [21].

\section{Microscopic examination of fungal isolates}

Morphological features of fungal isolates were studied using light microscopy after staining with lactophenol cotton blue. A drop of lactophenol cotton blue stain was placed in the centre of a clean slide. A small tuft of the fungus $(2-3 \mathrm{~mm})$ was transferred into the drop using an inoculating or teasing needle and teased gently. Preparation was examined under low and high, dry magnification for the presence of characteristic mycelia and fruiting structures [22].

\section{Identification of fungal isolates}

The fungal isolates with potential for esterase and Phytase production were submitted to Indian type culture collection (ITCC), Indian Agricultural Research Institute (IARI), New Delhi for their identification and characterization.

\section{Inoculum development}

Spore suspension of 6 days old slant was used to inoculate seed flask containing $10 \mathrm{ml} \mathrm{PDB}$ and maintained at $30^{\circ} \mathrm{C}$ and $200 \mathrm{rpm}$ for $48 \mathrm{~h}$. Spore counting was done using Neubauer counting chamber (Haemocytometer). Media was inoculated with $5 \times 10^{6} \mathrm{spores} / \mathrm{ml}$. After $48 \mathrm{~h}$ of growth, the culture was transferred to $100 \mathrm{ml} \mathrm{PDB}$ and was used as inoculum for both submerged and Solid State Fermentation. $0.5 \mathrm{ml}$ of inoculum with $0.53 \mathrm{~g}$ of fungal wet cell weight $(10 \% \mathrm{v} / \mathrm{w})$ was used to inoculate $5 \mathrm{~g}$ solid substrate in SSF. Similarly, $10 \mathrm{ml}$ inoculum with $5.3 \mathrm{~g}$ wet cell weight $(10 \% \mathrm{v} / \mathrm{v})$ was used to inoculate $100 \mathrm{ml}$ Potato dextrose broth in SmF

\section{Production of enzymes}

SmF setup for enzyme production: $100 \mathrm{ml}$ PBD was inoculated with $10 \mathrm{ml}(10 \%)$ inoculum and was kept at $30^{\circ} \mathrm{C}$ and $150 \mathrm{rpm}$ for $96 \mathrm{~h}$ with regular sampling after every $24 \mathrm{~h}$ [23]

SSF setup for enzyme production: $4 \mathrm{~g}$ of a solid substrate (wheat bran) was taken in a different flask $(250 \mathrm{ml})$ and inoculated with $2 \mathrm{ml}$ of spore suspension; flasks were kept static at $30^{\circ} \mathrm{C}$ for $96 \mathrm{~h}$ with regular sampling after every $24 \mathrm{~h}$. The enzyme was harvested by adding 16 $\mathrm{ml}$ of distilled autoclaved water and the fermented slurry was filtered through the muslin cloth. The resulting extract was used for the assay of enzyme activities [24].

Process parameter optimization for enzyme production during SSF: Different process parameters, i.e., relative humidity, amount of spore suspension that is to be added, overhead air space optimization, media composition with respect to addition of inducer components to the media that enhances the fungal growth, temperature optimization for optimum enzyme production, optimization of the percentage of substrate for optimum action of enzymes and $\mathrm{pH}$ optimization.

\section{Assay of enzymes}

Phytase assay was carried out using phytate dodecasodium salt as substrate by measuring the absorbance at $660 \mathrm{~nm}$ [21]. One enzyme unit $(\mathrm{U})$ was the amount of enzyme liberating $1 \mu \mathrm{mol}$ of inorganic phosphate per min under standard assay conditions. Pectin assay estimates the liberation of galacturonic acid generated from degradation of polygalacturonic acid by the activity of enzyme Pectinases measuring the absorbance at $575 \mathrm{~nm}$ [25]. One enzyme unit (U) was the amount of enzyme liberating $1 \mu \mathrm{mol}$ of polygalacturonic acid per min under standard assay conditions. Invertase assay estimates the liberation of sucrose and fructose generated from degradation of sucrose by the activity of invertase by taking absorbance at $540 \mathrm{~nm}$ [26]. One enzyme unit (U) was the amount of enzyme liberating $1 \mu \mathrm{mol}$ of Glucose and Fructose per min under standard assay conditions.

\section{Estimation of protein}

For estimation of protein content in the enzyme samples, Bradford assay was done using BSA standard by measuring wavelength at 595 $\mathrm{nm}$ [27].

\section{Partial purification of enzymes}

The enzyme was precipitated from extraction buffer by ammonium sulphate of varying cut off ranging from $10 \%-80 \%$. $\left(\mathrm{NH}_{4}\right)_{2} \mathrm{SO}_{4}$ was added to the extract and was stirred at $4^{\circ} \mathrm{C}$ for 5 hours and then centrifuged at $5000 \mathrm{rpm}$ for $30 \mathrm{~min}$ at $4^{\circ} \mathrm{C}$.

\section{Results and Discussion}

\section{Screening and of invertase, pectinase and phytase producing} isolates

Six fungal isolates were isolated from agricultural fields of Delhi, Chandigarh and Himachal Pradesh of which four showed the coproduction of phytase, pectinase and invertase. Pectinase and invertase were determined using plate assays (Figure 1) and phytase have been determined quantitatively (no plate assay has yet been reported). 
Citation: Garlapati VK, Maheswari N, Gupta A (2015) Isolation and Screening of Fungal Isolates for Multienzyme Production Through Submerged and Solid State Fermentations. J Bioprocess Biotech 5: 249 doi:10.4172/2155-9821.1000249

\section{Characterization of fungal strains}

Microscopic observation: Fruiting bodies of fungal isolates were stained and observed under a microscope, as shown in the Figure 2.

Biochemical characterization: Cultures were further characterized on the basis of their morphological and biochemical characteristics at Indian Type Culture Collection at Department of Plant Pathology, IARI, New Delhi. Results are shown in Table 1. The results shows that all the fungal isolates obtained from different agricultural field and showing coproduction of phytase, pectinase and invertase belong to genus Aspergillus sp. The Submerged Fermentation for culture maintenance; enzyme screening and production has been performed using YPD broth.

\section{Production of enzymes}

SmF studies for coproduction of multienzymes: Submerged Fermentation studies showed a steady rise in Invertase, Pectinase and Phytase coproduction till 96h after which decline in biomass and enzyme activities were observed. Fungal strains were grown for coproduction of phytase, pectinase and invertase in $\mathrm{SmF}$ for $96 \mathrm{~h}$. Results showed coproduction of phytase, pectinase and invertase activity by Aspergillus nidulans (JUIT 4) and Aspergillus niger (JUIT 5) to be better than other fungal isolates under study (Figure 3). It has been observed that the three enzyme production initially increased till $20 \mathrm{~h}$, which denotes the $\log$ phase and remains constant from for 20-40 h, which reflects their stationary phase and finally the activities declined which may be due to substrate limitation.

SSF studies for coproduction of multienzymes: Since, relative humidity is one of the important process parameters for fungal growth during SSF; studies were performed to grow the fungal strains under high relative humidity $(\mathrm{RH})$ and water activity (aw). A varying volume of distilled water mixed with a dry substrate and relative humidity has been analyzed using Hygrometer (Table 2). Fungal strains were screened for coproduction of phytase, pectinase and invertase using wheat bran as a substrate. A maximum productivity of phytase, pectinase and invertase activities were seems to be equal to at $96 \mathrm{~h}$ by $A$. nidulans (JUIT 4) and A. niger (JUIT 5). It can be seen from Table 2 above that supplementation of wheat bran with water beyond $4 \mathrm{ml} / 4 \mathrm{~g}$ wheat bran does not produce any significant variation in relative humidity. Further studies at $90 \% \mathrm{RH}$ were performed with $4 \mathrm{ml}$ distilled water supplementation to $4 \mathrm{~g}$ wheat bran.

The best results for multi enzyme production in case of JUIT2 have been shown at $0.4 \%$ and $3.2 \%$ water activity for phytase \& invertase and pectinase respectively. The best results for multi enzyme production in case of JUIT4 have been shown at $0.4 \%$ water activity in case of Invertase, Pectinase and Phytase. The best results (Figure 4) for multi enzyme production in case of JUIT5 have been shown at $0.4 \%$ water activity in case of phytase, pectinase and invertase. The best results for multi enzyme production in case of JUIT6 have been shown at $0.4 \%$ water activity in case of phytase, pectinase and invertase. The overall results in the case of Solid State Fermentation with respect to the effect of water activity have been shown best in case of all four fungi, especially JUIT4 and JUIT5. The multi enzyme production has been shown at $0.4 \%$ water activity that corresponds to $67 \%$ relative humidity.

Comparison of SmF and SSF: Invertase, Pectinase and Phytase production in SmF \& SSF was compared on PDB and wheat bran respectively. Enzyme activities are shown in Figure 5.The results are in agreement with some of the previous reports showing improvement in the production of enzymes in SSF compared to SmF. It was also

observed that among all the fungal strains under study, Aspergillus nidulans (JUIT 4) and Aspergillus niger (JUIT 5) showed the highest coproduction of the enzymes and were used for further studies. Solid State Fermentation showed many fold increase in the production of invertase than Submerged Fermentation. JUIT2 and JUIT5 showed the maximum increase in the invertase production in SSF. Solid State Fermentation showed many fold increase in the production of pectinase than Submerged Fermentation. JUIT6 and JUIT5 showed the maximum increase in the pectinase production in SSF whereas JUIT4 showed a decline in Pectinase Production in SSF. Results for JUIT2 in SSF and SmF are comparable.The decline in results with JUIT4 as well as JUIT2, has been attributed to one of the reasons such as build up of gradient temperature, $\mathrm{PH}$, moisture, substrate concentration or $\mathrm{pO}_{2}$ during cultivation (which are difficult to control under limited water availability).Solid State Fermentation showed many fold increase in the production of Phytase than Submerged Fermentation. JUIT2, JUIT4 and JUIT6 showed the maximum increase in the Phytase production in SSF whereas JUIT5 showed comparable results in the case of SSF and $\mathrm{SmF}$ although a slight increase in SSF is seen in this case also.

Reasons for the increased production of enzymes in SSF over SmF include better productivity because of higher biomass production and lower protein breakdown, less catabolic repression, low water demand, and hence low sterlity demand due to low water activity, cultivation of

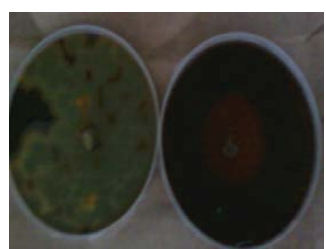

A (JUIT2 on the left)

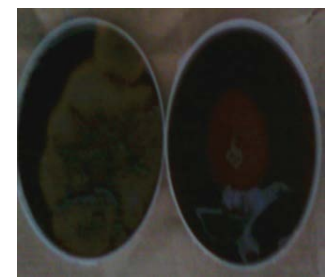

C (JUIT5 on the left)
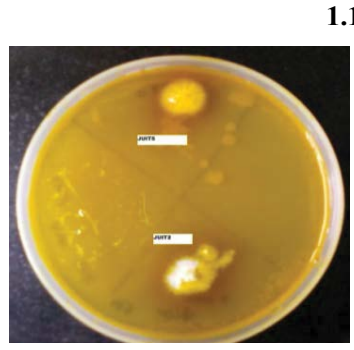

A. (JUIT5 on top; JUIT2 below)

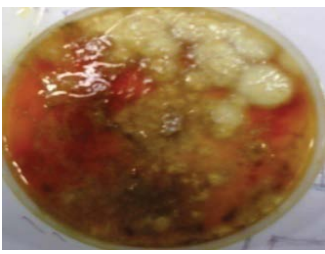

C. (JUIT6)

1.2

Figure 1: Plate assays for (1.1) Pectinase (1.2) Invertase. 

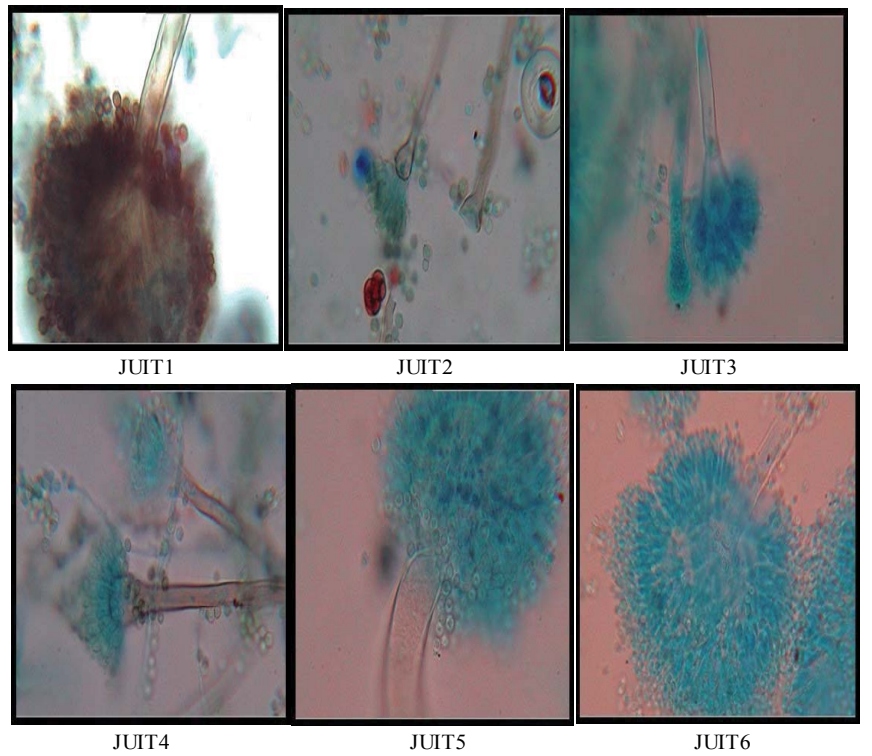

Figure 2: Lactophenol cotton blue staining of fungal isolates.

\begin{tabular}{|c|c|}
\hline Fungi & Characterization \\
\hline JUIT1 & Aspergillus niger \\
\hline JUIT2 & Aspergillus niger \\
\hline JUIT3 & Aspergillus fumigates \\
\hline JUIT4 & Aspergillus nidulans \\
\hline JUIT5 & Aspergillus niger \\
\hline JUIT6 & Aspergillus oryzae \\
\hline
\end{tabular}

Table 1: Characterization results of fungal isolates.

microbes requiring a solid support and mixed cultivation of various fungi. Catabolite repression or protein degradation by proteases are severe problems in SmF were often reduced or absent in SSF [28]. In contrast, much less research attempts have been done for metabolic differences evaluation of microorganisms, cultivated in SSF or SmF. The biological parameters of enzymes produced through SSF such as stability at high temperature or extreme has been seems to be better than SmF enzymes [29].

\section{Selection of SSF conditions}

Effect of various parameters on solid state fermentation: Apart from relative humidity, the SSF parameters such as amount of spore suspension, overhead airspace, inducer for the fungal growth, temperature, percentage of substrate, and $\mathrm{pH}$ plays an important role in obtaining the optimized yield of multienzymes.

Effect of the amount of spore suspension and overhead airspace: Different volumes $(0.2-6 \mathrm{ml})$ of distilled water were added to the fungal slants and the spores were scratched using a loophole under sterilized conditions in a laminar air hood chamber. These volumes of spore suspensions were separately inoculated in plate fermentation set up and flask $(250 \mathrm{ml})$ fermentation set up of JUIT4 and JUIT5.

Enzyme activities were measured from each setup. It was found that $2 \mathrm{ml}$ of a spore suspension of JUIT4 as well as JUIT5 was good enough for coproduction of all three enzymes and that flask fermentation is better than plate fermentation that shows more overhead air space is beneficial for coproduction of Invertase, Pectinase and Phytase
(Data was not shown). A maximum multi enzyme production in case of JUIT4 has been shown when spore suspension of $2 \mathrm{ml}$ has been taken and when more overhead space is provided. Flask fermentation has proved to be better than plate fermentation for the production of Invertase, Pectinase and Phytase. The maximum multi enzyme production in case of JUIT5 has been shown when spore suspension of $2 \mathrm{ml}$ has been taken and when more overhead space is provided (Data was not shown). Flask fermentation has proved to be better than plate fermentation for the production of Invertase, Pectinase and Phytase.

Effect of inducers: Various inducer substances were taken and were screened to check their effect in increasing enzyme activities. Sorbitol, Mannitol, Maltose, Lactose, Sucrose, Phytic acid and Dextrose were taken as inducers. $20 \%$ concentration of these inducers with respect to 4 gms wheat bran was added separately and enzyme activities were measured about each inducer added (Data was not shown). Maltose was found to coproduce all three enzymes in comparatively higher concentrations.

Effect of temperature: Various temperatures $\left(25-37^{\circ} \mathrm{C}\right)$ were tested for the effect of varying temperature conditions on JUIT4 and JUIT5 for coproduction of Invertase, Pectinase and Phytase. The optimized inoculum/spore suspension $(2 \mathrm{ml})$, overhead air space (250 $\mathrm{ml}$ flask) and inducer (maltose, $20 \%$ ) were taken into consideration. It was found that the highest levels of enzymes were produced at $30^{\circ} \mathrm{C}$ temperature (Data was not shown).

\section{Partial purification of enzymes}

The enzyme was precipitated from extraction buffer by ammonium sulphate of varying cut-off ranging from $10 \%-80 \%$ through salting out method. Precipitation is due to the bonding between water molecules and ammonium sulphate added, and as a result, the protein molecules that were earlier bonded with water are now free and due to hydrophobic effects get attached to one another and are finally precipitated. A maximum enzyme activities of Invertase, Pectinase and Phytase has been observed using $70 \%$ cut-off for JUIT4 and 30\% cut off for JUIT5 (Data was not shown).

\section{Effect of $\mathrm{pH}$ on enzyme activity}

Various $\mathrm{pH}(3,4.2,5,6.2,7.6,8.2$ and 8.9) were used to check the enzyme stability and to measure in which $\mathrm{PH}$ the enzymes are produced sufficiently. The optimized inoculum/spore suspension $(2 \mathrm{ml})$, overhead air space (250 ml flask), inducer (maltose, $20 \%$ ) and a growth temperature $\left(30^{\circ} \mathrm{C}\right)$ were taken into consideration. The protein-rich broth recovered after the harvesting was subjected to centrifugation to remove the debris, a small amount of crude sample was kept for comparative analysis with ammonium sulphate precipitated protein (30\% for JUIT5 and $70 \%$ for JUIT4). It was seen that Phytase activity was found maximum at $\mathrm{pH} 6.2$, Invertase activity was found maximum between $\mathrm{pH} 3$ to $\mathrm{pH} 5$ and Pectinase activity was found maximum between $\mathrm{pH} 5$ to $\mathrm{pH}$ 6.2.(Data was not shown). The stability of most plant phytases decreased dramatically at $\mathrm{pH}$ values below 4 and above 7.5 , while the majority of the corresponding microbial enzymes are stable even at $\mathrm{pH}$ values above 8.0 and below 3.0 [30]. Broad $\mathrm{pH}$ optima, thermal stability as well as a higher specific activity of microbial phytase make it more favorable for an application in food and feed industries.

\section{Conclusion}

Current study proposes the selection of bioprocess conditions for multi-enzyme production through SSF and SmF. A comparison of invertase, pectinase and phytase co-production by four soil fungal 
Citation: Garlapati VK, Maheswari N, Gupta A (2015) Isolation and Screening of Fungal Isolates for Multienzyme Production Through Submerged and Solid State Fermentations. J Bioprocess Biotech 5: 249 doi:10.4172/2155-9821.1000249

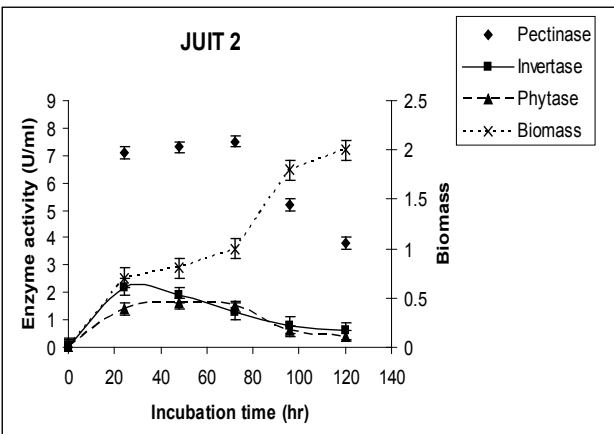

(a)

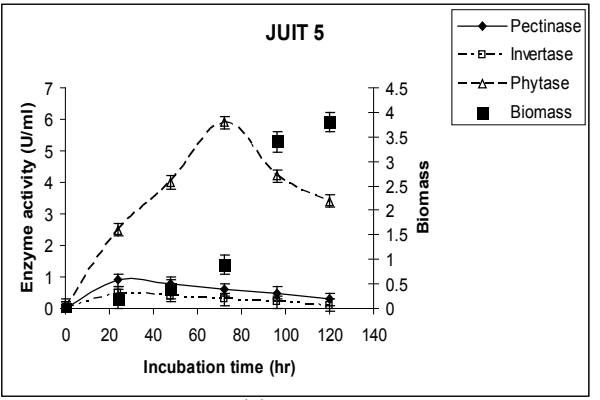

(c)

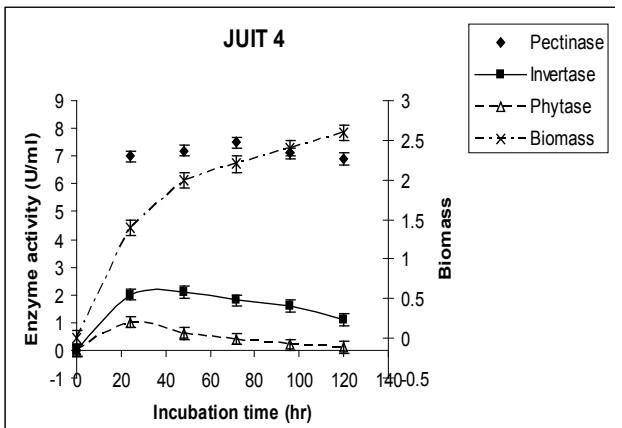

(b)

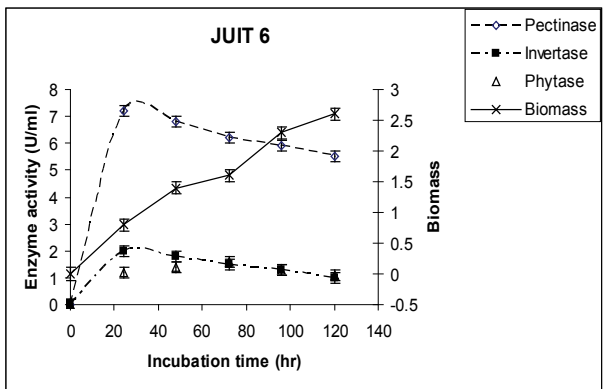

(d)

Figure 3: Effect of incubation time enzyme production through SmF (a) JUIT2 (b) JUIT4 (c) JUIT5 (d) JUIT6. All values are represented as \pm s.d of three replications.

\begin{tabular}{|c|c|c|}
\hline Water added to $\mathbf{4}$ gms Wheat Bran (ml) & Relative Humidity (\%) & Water activity (aw) \\
\hline 0.4 & $67 \%$ & 0.67 \\
\hline 1.2 & $76 \%$ & 0.76 \\
\hline 3.2 & $87 \%$ & 0.87 \\
\hline 4 & $90 \%$ & 0.90 \\
\hline
\end{tabular}

Table 2: Effect of relative humidity and water activity on water supplemented solid substrate.

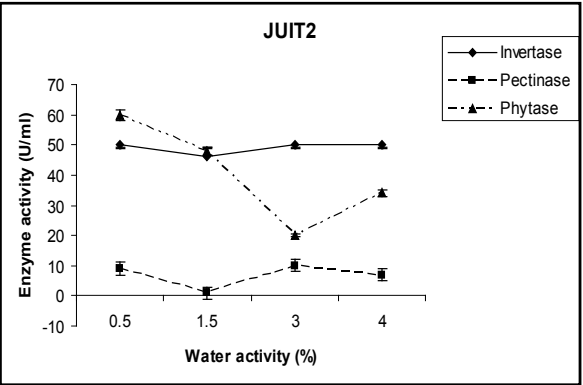

(a)

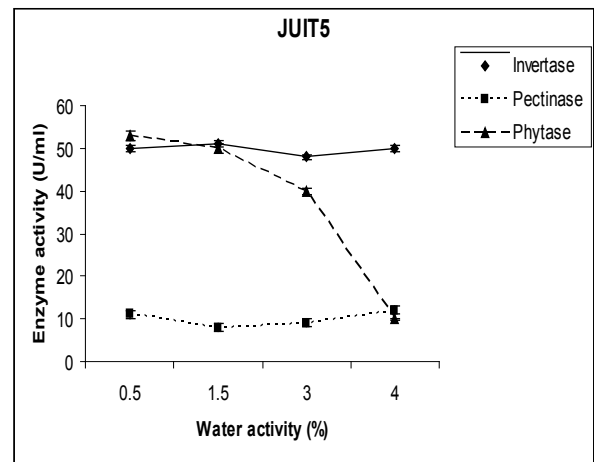

(c)

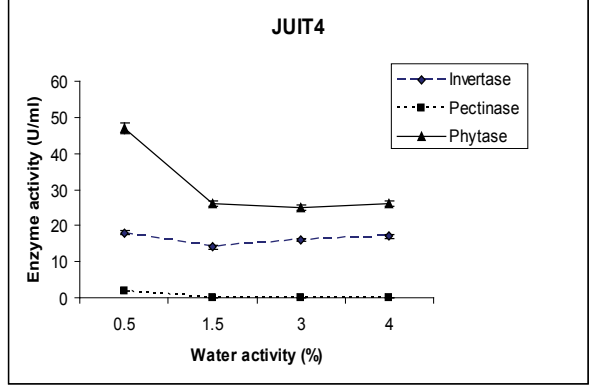

(b)

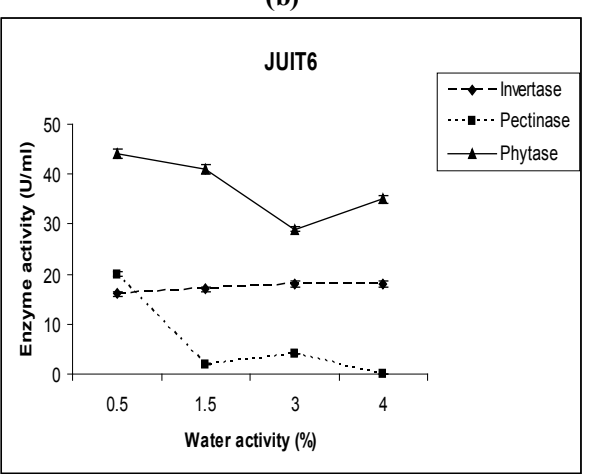

(d)

Figure 4: Effect of water activity on enzyme production through SSF (a) JUIT2 (b) JUIT4 (c) JUIT 5 (d) JUIT 6. All values are represented as \pm s.d of three replications. 
Citation: Garlapati VK, Maheswari N, Gupta A (2015) Isolation and Screening of Fungal Isolates for Multienzyme Production Through Submerged and Solid State Fermentations. J Bioprocess Biotech 5: 249 doi:10.4172/2155-9821.1000249

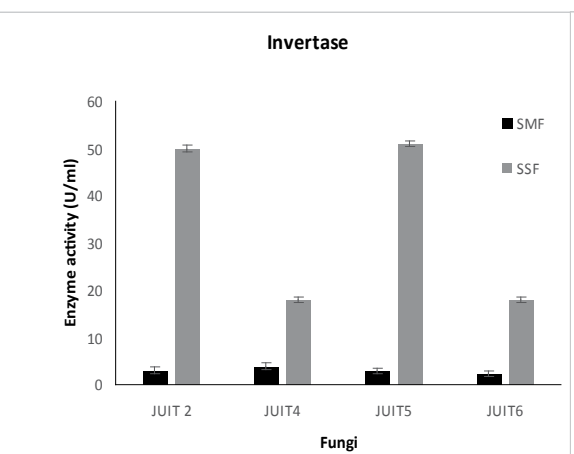

(a)

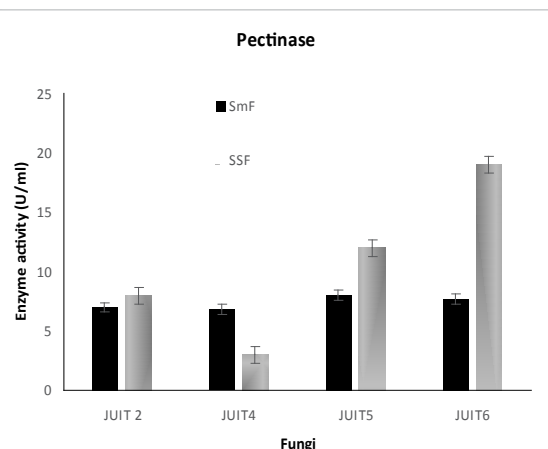

(b)

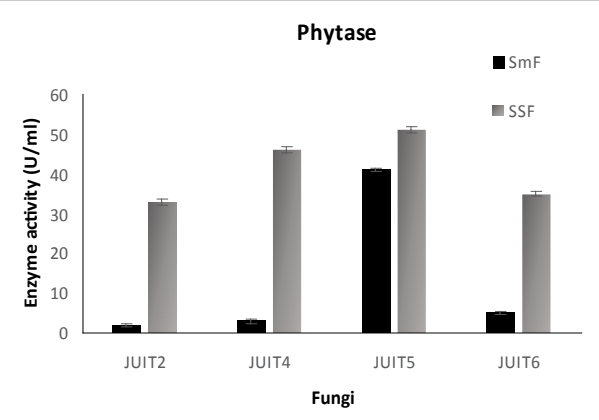

(c)

Figure 5: Comparision of SmF and SSF for (a) invertase (b) pectinase (c) phytase production. All values are represented as \pm s.d of three replications.

isolates has been studied. Significant improvements in Invertase, Pectinase and Phytase activities have been observed in case of JUIT4 and JUIT5. Further studies were performed using the two chosen fungal strains, A.nidulans (JUIT 4) and A.niger (JUIT 5). The selection of relative humidity, inoculum used, overhead space, growth temperature, inducers added, substrate concentration and $\mathrm{pH}$ for coproduction of phytase, pectinase and invertase during SSF has been carried out. A strong interaction has been observed between the all the bioprocess parameters in enzyme production by same fungal strain. Partial purification of enzymes has been done for further subsequent studies of this multienzyme complex.

\section{Acknowledgement}

The authors gratefully acknowledge JUIT, India, for providing research fellowship and research facilities to Ankit Gupta and Nikita Maheswari.

\section{References}

1. Vohra A, Satyanarayana T (2003) Phytases: microbial sources, production, purification, and potential biotechnological applications. Crit Rev Biotechnol 23: 29-60.

2. Casey A, Walsh G (2003) Purification and characterization of extracellular phytase from Aspergillus niger ATCC 9142. Bioresour Technol 86: 183-188.

3. Sharma N, Rathore M, Sharma M (2013) Microbial pectinase: sources, characterization and applications. Rev Environ Sci Biotechnol 12: 45-60.

4. Awad GE, Amer H, El-Gammal EW, Helmy WA, Esawy MA, et al. (2013) Production optimization of invertase by Lactobacillus brevis Mm-6 and its immobilization on alginate beads. Carbohydr Polym 93: 740-746.

5. Sapna, Singh B (2013) Improved production of protease-resistant phytase by Aspergillus oryzae and its applicability in the hydrolysis of insoluble phytates. $J$ Ind Microbiol Biotechnol 40: 891-899.

6. Pandey A, Selvakumar P, Soccol CR, Nigam P (1999) Solid state fermentation for the production of industrial enzymes. Curr Sci 77: 149-162.

7. Volfová O, Dvoráková J, Hanzlíková A, Jandera A (1994) Phytase from Aspergillus niger. Folia Microbiol (Praha) 39: 481-484.
8. Perrone G, Mulè G, Susca A, Battilani P, Pietri A, et al. (2006) Ochratoxin A production and amplified fragment length polymorphism analysis of Aspergillus carbonarius, Aspergillus tubingensis, and Aspergillus niger strains isolated from grapes in Italy. Appl Environ Microbiol 72: 680-685.

9. Takao M, Nakaniwa T, Yoshikawa K, Terashita T, Sakai T (2000) Purification and characterization of thermostable pectate lyase with protopectinase activity from thermophilic Bacillus sp. TS 47. Biosci Biotechnol Biochem 64: 2360-2367.

10. Maiorano AE, Schmidell W, Ogaki $Y$ (1995) Determination of the enzymatic activity of pectinases from different microorganisms. World $\mathrm{J}$ Microbio Biotechnol 11: 355-356.

11. Sutton MD, Peterson JBD (2001) Fermentation of sugarbeet pulp for ethanol production using bioengineered Klebsiella oxytoca strain P2. J Sugar Beet Res 38: 19-34.

12. Silversides FG, Scott TA, Korver DR, Afsharmanesh M, Hruby M (2006) A study on the interaction of xylanase and phytase enzymes in wheat-based diets fed to commercial white and brown egg laying hens. Poult Sci 85: 297-305.

13. Cowieson AJ, Adeola O (2005) Carbohydrases, protease, and phytase have an additive beneficial effect in nutritionally marginal diets for broiler chicks. Poult Sci 84: 1860-1867.

14. Juanpere J, Pérez-Vendrell AM, Angulo E, Brufau J (2005) Assessment of potential interactions between phytase and glycosidase enzyme supplementation on nutrient digestibility in broilers. Poult Sci 84: 571-580.

15. Zaghloul TI, Abdel Wahab AE, Mostafa MH (2000) Enhanced alkaline protease production in addition to alpha-amylase via constructing a Bacillus subtilis strain. Appl Biochem Biotechnol 84-86: 319-27.

16. Zhang C, Xing XH, Liu MS (2004) Production of multienzymes consisting of alkaline amylase and cellulase by mix ed alkalophilic culture and their potential use in the saccharification of sweet potato. Biochem Eng J 19: 181-187.

17. Aguilar CN, Gerardo G, Plilia A, Juan CC (2008) Perspectives of Solid State Fermentation for Production of Food Enzymes. Am J Biochem Biotechnol 4 354-366.

18. Mamma D, Kourtoglou E, Christakopoulos P (2008) Fungal multienzyme production on industrial by-products of the citrus-processing industry. Bioresour Technol 99: 2373-2383. 
Citation: Garlapati VK, Maheswari N, Gupta A (2015) Isolation and Screening of Fungal Isolates for Multienzyme Production Through Submerged and Solid State Fermentations. J Bioprocess Biotech 5: 249 doi:10.4172/2155-9821.1000249

19. Delabona PS, Pirota RDPB, Codima CA, Tremacoldi CR, Rodrigues A, et al. (2013) Effect of initial moisture content on two Amazon rainforest Aspergillus strains cultivated on agro-industrial residues: Biomass-degrading enzymes production and characterization. Ind Crop Prod 42: 236-242.

20. Boyce A, Casey A, Walsh G (2004) A phytase enzyme-based biochemistry practical particularly suited to students undertaking courses in biotechnology and environmental science. Biochem Mol Biol Educ 32: 336-340.

21. Spier MR, Greiner R, Rodriguez -Leon JA,Woiciechowski AL, Pandey A, et al. (2008) Phytase production using citric pulp and other residues of the agro industry in SSF by fungal isolates. Food Technol Biotechnol 46: 178-182.

22. Ivanova A, Marfenina $O$ (2015) Soil fungal communities as bioindicators of ancient human impacts in medieval settlements in different geographic regions of Russia and southwestern Kazakhstan. Quat Int 365: 212-222.

23. Papagianni M (2004) Fungal morphology and metabolite production in submerged mycelial processes. Biotechnol Adv 22: 189-259.

24. Graminha EBN, Gonçalves AGL, Pirota RDPB, Balsalobre MAA, Da Silva, et al. (2008) Enzyme production by solid-state fermentation: Application to animal nutrition. Anim Feed Sci Technol 144: 1-22.
25. Combo AMM, Aguedo M, Goffin D, Wathelet B, Paquot M (2012) Enzymatic production of pectic oligosaccharides from polygalacturonic acid with commercial pectinase preparations. Food Bioprod Process 90: 588-596.

26. Amaya-Delgado L, Hidalgo-Lara ME, Montes-Horcasitas MC (2006) Hydrolysis of sucrose by invertase immobilized on nylon- 6 microbeads. Food Chem 99 : 299-304

27. Lowry OH, Rosebrough NJ, Farr AL, Randall RJ (1951) Protein measurement with the Folin phenol reagent. J Biol Chem 193: 265-275.

28. Aguilar CN, Augur C, Favela-Torres E, Viniegra-González G (2001) Induction and repression patterns of fungal tannase in solid-state and submerged cultures. Process Biochem 36: 565-570.

29. Acuña-Argüelles ME, Gutiérrez-Rojas M, Viniegra-González G, Favela-Torres E (1995) Production and properties of three pectinolytic activities produced by Aspergillus niger in submerged and solid-state fermentation. Appl Microbiol Biotechnol 43: 808-814.

30. Cao L, Weimin W, Dapeng L (2007) Application of microbial phytase in fish feed. Enzyme Microb Tech 40: 497-507. 